\title{
Sea-ice thickness variability in Storfjorden, Svalbard
}

\author{
S. HENDRICKS, ${ }^{1}$ S. GERLAND, ${ }^{2}$ L.H. SMEDSRUD, ${ }^{3}$ C. HAAS, ${ }^{4}$ \\ A.A. PFAFFHUBER, ${ }^{5}$ F. NILSEN ${ }^{6,7}$ \\ ${ }^{1}$ Alfred Wegener Institute for Polar and Marine Research, Bussestrasse 24, D-27570 Bremerhaven, Germany \\ E-mail: stefan.hendricks@awi.de \\ ${ }^{2}$ Norwegian Polar Institute, Fram Centre, Hjalmar Johansens gate 14, NO-9296 Tromsø, Norway \\ ${ }^{3}$ Bjerknes Centre for Climate Research, University of Bergen, Allégaten 55, NO-5007 Bergen, Norway \\ ${ }^{4}$ Department of Earth \& Atmospheric Sciences, University of Alberta, Edmonton, Alberta T6G 2E3, Canada \\ ${ }^{5}$ Norwegian Geotechnical Institute, PO Box 3930, Ullevål Stadion, NO-0806 Oslo, Norway \\ ${ }^{6}$ The University Centre in Svalbard (UNIS), PO Box 156, NO-9171 Longyearbyen, Norway \\ ${ }^{7}$ Geophysical Institute, University of Bergen, PO Box 1870 Nordnes, NO-5817 Bergen, Norway
}

\begin{abstract}
Results from electromagnetic induction surveys of sea-ice thickness in Storfjorden, Svalbard, reveal large interannual ice-thickness variations in a region which is typically characterized by a reoccurring polynya. The surveys were performed in March 2003, May 2006 and March 2007 with helicopter- and ship-based sensors. The thickness distributions are influenced by sea-ice and atmospheric boundary conditions 2 months prior to the surveys, which are assessed with synthetic aperture radar (SAR) images, regional QuikSCAT backscatter maps and wind information from the European Centre for Medium-Range Weather Forecasts (ECMWF) reanalysis dataset. Locally formed thin ice from the Storfjorden polynya was frequently observed in 2003 and 2007 (mean thickness $\mathbf{0 . 5 5}$ and $0.37 \mathrm{~m}$, respectively) because these years were characterized by prevailing northeasterly winds. In contrast, the entire fjord was covered with thick external sea ice in 2006 (mean thickness $2.21 \mathrm{~m}$ ), when ice from the Barents Sea was driven into the fjord by predominantly southerly winds. The modal thickness of this external ice in 2006 increased from $1.2 \mathrm{~m}$ in the northern fjord to $2.4 \mathrm{~m}$ in the southern fjord, indicating stronger deformation in the southern part. This dynamically thickened ice was even thicker than multi-year ice advected from the central Arctic Ocean in 2003 (mean thickness $1.83 \mathrm{~m}$ ). The thermodynamic ice thickness of fast ice as boundary condition is investigated with a onedimensional sea-ice growth model (1DICE) forced with meteorological data from the weather station at the island of Hopen, southeast of Storfjorden. The model results are in good agreement with the modal thicknesses of fast-ice measurements in all years.
\end{abstract}

\section{INTRODUCTION}

Sea-ice conditions in Storfjorden during winter are typically characterized by the formation of a reoccurring polynya (Haarpaintner and others, 2001). The fjord, situated in the southeastern part of the Svalbard archipelago, is enclosed by the islands of Spitsbergen to the northwest and Edgeøya to the east (see Fig. 1) such that the coastal polynya opens at northerly winds. Polynya activity results in the formation of brine-enriched shelf water, and the volume produced in Storfjorden can be significant compared with the total amount of bottom water in the Arctic (Skogseth and others, 2004).

However, in regions surrounded by coastlines like Storfjorden, the potential for ice deformation is also strong when winds are directed onshore. These processes may form much thicker sea ice by dynamic thickening than could be formed by thermodynamic growth. In the Arctic Ocean, for example, the thickest and most deformed sea ice can be found in the Lincoln Sea (Haas and others, 2006), where the coastlines of the Canadian Arctic Archipelago are a natural barrier against the dominating sea-ice drift pattern. For Storfjorden, external sea ice from the Barents Sea may be advected into the central fjord at southerly winds, which can lead to significant dynamic ice growth. Little information exists about these events and resulting thicknesses, since ice-thickness datasets of Svalbard fjords were only available from the accessible fast-ice zones (e.g. Gerland and Hall, 2006; Gerland and others, 2008) due to logistical and safety constraints.
Here we present sea-ice thickness data obtained by airborne and ship-based field campaigns in Storfjorden in spring 2003, 2006 and 2007. The aim of this study was to assess for the first time the general sea-ice thickness distribution in Storfjorden in years with different external sea-ice and atmospheric conditions. Remote-sensing data and reanalysis data of the general atmospheric circulation patterns 2 months prior to the surveys are used for the interpretation of the collected ice-thickness distributions. Thermodynamic ice growth is studied with fast-ice thickness measurements and a one-dimensional (1-D) ice growth model (1DICE). Data from central Storfjorden were collected to understand the relative importance of differences in thermodynamic and dynamic ice growth. The latter also has direct relevance for ice-thickness distributions in other Arctic regions and for parameterizations of dynamic thickness changes in climate models.

\section{DATA AND METHODS}

\section{Ice-thickness measurements}

Ice-thickness data were collected in the study region of Storfjorden during 3 years by means of electromagnetic (EM) induction sounding (Fig. 2). In March 2003, RV Polarstern served as a base for helicopter-borne EM (HEM) surveys (Haas and others, 2004). Starting at the southern entrance of the fjord, four flights with a total profile length of $510 \mathrm{~km}$ 


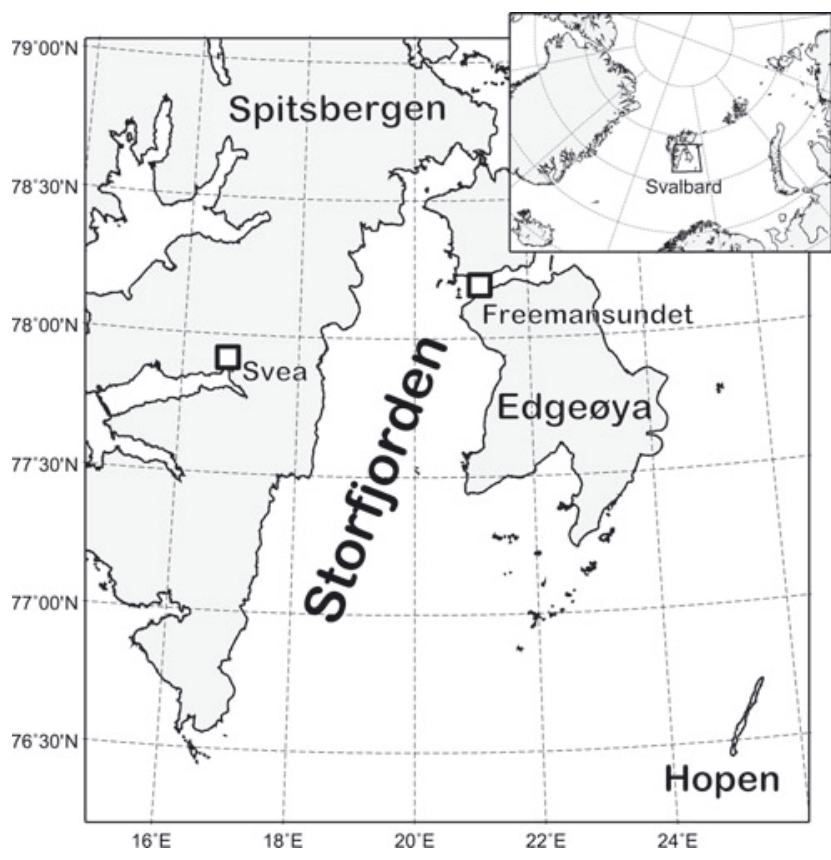

Fig. 1. Map of the study region. Storfjorden is enclosed by Spitsbergen to the west and Edgeøya to the east. Both islands are part of the Svalbard archipelago in the western Barents Sea.

were performed between $76.8^{\circ} \mathrm{N}$ and $78.2^{\circ} \mathrm{N}$ between 12 and 17 March. In the northern part of the fjord, two flights resemble a north-south and east-west pattern yielding zonal and meridional cross sections. In the southern part, where the fjord is wider, the flight patterns were triangular for optimal area coverage.

The second survey was performed on 2 May 2006. This time the flight was started at the coal mine facility, Svea, on Spitsbergen (see Fig. 1). The survey was conducted in two flight legs (total length $448 \mathrm{~km}$ ) over the entire study region, with one transect from $77.08^{\circ} \mathrm{N}$ to $78.64^{\circ} \mathrm{N}$ along the $20^{\circ} \mathrm{W}$ meridian. It was completed with several more zonal sections between Spitsbergen and Edgeøya.

In 2007, observations were carried out by ship-borne EM with the Norwegian coastguard vessel KV Svalbard between 22 and 25 March (A. Pfaffling, http://www/pfafflinggeophysics.com). The area of data collection is more limited than in the previous years when helicopters were used. The survey ranged from the southernmost point at $77.08-78.17^{\circ} \mathrm{N}$ to Freemansundet north of Edgeøya, and ice-thickness observations were more centered towards the eastern side of the fjord $\left(19-21^{\circ} \mathrm{W}\right)$.

EM induction sounding is a common technique for seaice thickness retrieval using airborne (Kovacs and others, 1987; Haas and others, 2009) and ship-based (Haas, 1998; Uto and others, 2006) platforms. The airborne surveys were carried using a custom-built sensor (Haas and others, 2009), while for the ship-borne measurements a commercial sensor (Geonics EM31 MkII) was used. The EM technique utilizes the strong electrical conductivity contrast between the conductive sea water and resistive sea ice. Here we use the secondary EM field induced by a set of transmitter and receiver coils at the ice-water interface to estimate the height of the sensor above the bottom of the ice. This height can be obtained by inversion of a theoretical curve derived by calculating the EM response for variable heights above sea water of known conductivity using a forward model (Anderson, 1979; Haas and others, 2009). We assumed a sea-water conductivity of $2700 \mathrm{mS} \mathrm{m}^{-1}$ and a negligible seaice conductivity of $0 \mathrm{mS} \mathrm{m}^{-1}$. Ice thickness results from the difference of the sensor's height above the ice bottom and surface. The latter is measured with a laser altimeter. As the altimeter signals are reflected at the top of the snow the EM thickness includes both snow and ice thickness, i.e. represents total thickness. However, in this study we use the term ice thickness as a synonym for 'total thickness'. Over level sea ice, the accuracy of the EM method is $\pm 0.1 \mathrm{~m}$ (Haas,
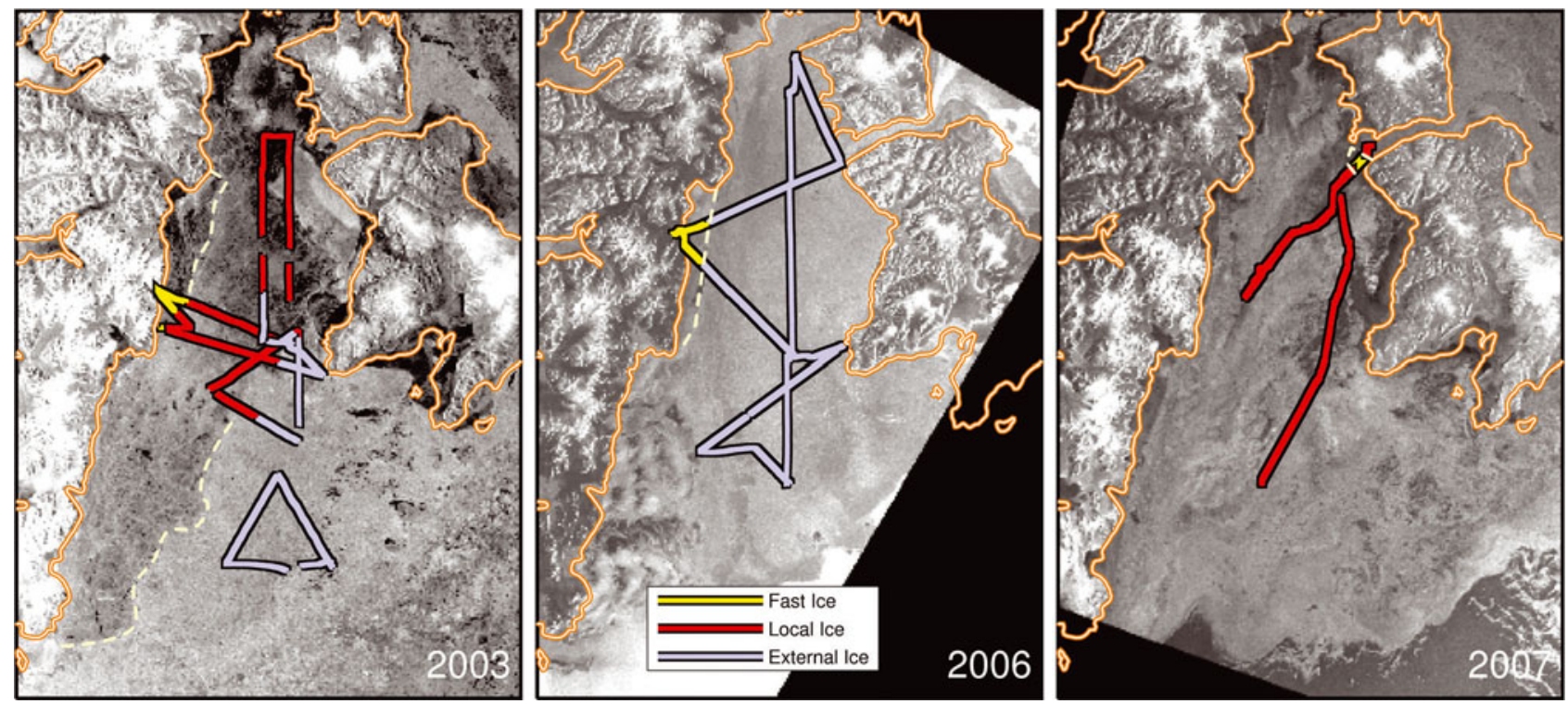

Fig. 2. Ice-thickness profiles in the Storfjorden area in 2003, 2006 and 2007. Based on SAR scenes (background image) from Envisat (wide swath mode, resolution $150 \mathrm{~m}$ ) and ice thickness, the data points were classified into regions of fast ice (yellow), locally formed ice (red) and external sea ice (blue). Dashed lines mark manually identified boundaries between ice classes in the SAR scenes. In 2003, the boundary between local and external sea ice in the SAR scene deviates from the classification result due to the offset of several days between helicopter survey and image acquisition. 
1998; Pfaffling and others, 2007; Haas and others, 2009; A. Pfaffling, http://www.pfaffling.geophysics.com). In areas with small-scale ice-thickness variations like pressure ridges, the interpretation of the retrieved EM thickness is influenced by its footprint. This footprint is defined as the area where the main induction process at the ice-water interface occurs. Studies (Reid and Vrbancich, 2004; Reid and others,

2006) have shown that the footprint depends on the instrument characteristics, the operational altitude and the sea-water conductivity. For the HEM system, the footprint is approximately four times the corresponding height above the ocean, yielding values of $40-50 \mathrm{~m}$ at common operational altitudes. The thickness of pressure ridges may therefore be underestimated by as much as $50 \%$ due to the footprint smoothing of the EM method (Haas and Jochmann, 2003; Pfaffling and Reid, 2009). However, simulations using a three-dimensional EM forward model have shown that mean EM thicknesses across ridges agree closely with the true mean thickness (Hendricks, 2008).

One issue when comparing ship and airborne EM data is the statistical selection bias due to the different platforms. While helicopter surveys can be conducted with constant speed and arbitrary flight patterns, ships are influenced directly by the ice conditions. In heavy ice conditions ships slow down and sometimes resort to ramming of ridges, hence thick sea ice will be overrepresented in the thickness distribution. Therefore, the 2007 ice-thickness data were resampled along the cruise track to the average point spacing of the airborne measurements of roughly $4 \mathrm{~m}$ to minimize the statistical bias of preferential sampling of certain thickness classes.

\section{Sea-ice conditions}

Satellite data were acquired to assist the interpretation of ice conditions in a wider area than the data collection. First, synthetic aperture radar (SAR) images from the Envisat satellite (wide swath mode with resolution of $150 \mathrm{~m}$ ) were used for a manual classification of the profiles into three categories based on the backscatter characteristics: (1) fast ice; (2) locally formed ice; and (3) external sea ice advected from the Barents Sea into the study area. The regional distribution of the classes is shown in Figure 2. The advected sea ice can be separated from the local ice in the SAR images by its brighter appearance due to the higher backscatter of the rougher ice surface. Locally formed thin ice is generally characterized by dark patches of low backscatter. The fast-ice edge was identified manually by its appearance as a bright line, which separates a uniform backscatter region close to the coast from the more heterogeneous sea ice in the central fjord.

Sea-ice conditions outside Storfjorden in a time frame of 2 months prior to the measurements are investigated with QuikSCAT backscatter products as shown in Figure 3. In the QuikSCAT maps, older or deformed sea ice can be identified by higher backscatter; correspondingly, the smoother surface and the higher salinity of first-year ice appears as low backscatter values. The ice edge based on the 15\% threshold of Special Sensor Microwave/Imager (SSM/I) sea-ice concentration data is included in Figure 3 to assist the discrimination between low-backscatter sea ice and open water.

In 2003, a large outflow event (Kwok and others, 2005) from the Arctic Ocean resulted in a high concentration of multi-year ice along the eastern coastlines of the Svalbard archipelago as far as the southern part of the Storfjorden area. In the following field campaigns, this region east of Edgeøya was either covered by first-year sea ice (2007) or was completely ice-free due to the later date of the field campaign at the beginning of May 2006 and interannual variability of ice conditions in this region. The western site of the Svalbard archipelago is always ice-free due to the influence of the warm West Spitsbergen Current.

Weather information from European Centre for MediumRange Weather Forecasts (ECMWF) reanalysis data shows the history of the Storfjorden atmospheric forcing in the 2 months prior to the data collection (Fig. 4). The actual wind direction may differ from the reanalysis data due to the topography effects of the surrounding islands, but in situ observations are not available in all years and data from the closest weather station, on the island of Hopen, are compromised by the same problem. However, the histograms of wind direction in Figure 4 show the general characteristics of atmospheric forcing sufficiently well. In all years a strong northeasterly component existed in the 2 months before the thickness surveys. This dominant wind direction is the driver of the Storfjorden polynya and is not only most frequent but also shows on average the highest wind speeds. Figure 4 shows quite similar atmospheric forcing for the ice cover in 2003 and 2007, while in 2006 an additional more frequent southerly wind component exists. Under these conditions the inner fjord will be covered with a close ice pack advected from the south, possibly resulting in heavy ice deformation.

\section{Thermodynamic growth model}

A thermodynamic sea-ice growth model is used to assess the thermodynamic component of the sea-ice thickness distributions. The 1DICE column model uses daily time-steps and calculates the horizontally averaged ice thickness and ocean column below (Björk, 1989, 1997). The model set-up has a $1 \mathrm{~m}$ vertical resolution. Runs were initialized on 1 September in the year previous to the spring field campaigns and performed for 1 year. The water column starts at the freezing point and without initial sea-ice cover. One sea-ice class is used, taken to represent undeformed first-year sea ice. Fast ice attached to land along the Svalbard coast is a good example of such an ice type. The 1DICE model calculates all relevant fluxes of heat and mass based on the monthly averaged forcing of the atmosphere. The runs presented here differ only in monthly mean surface temperature. Airtemperature values from Hopen island to the south of Storfjorden (Fig. 1) are used, as data inside Storfjorden are not available in all years. Typically, the meteorological station on Hopen shows $1^{\circ} \mathrm{C}$ warmer air temperatures than in Storfjorden (Skogseth and others, 2004). Sensible heat fluxes are estimated from air temperature and wind speed (mean and standard deviations) using standard bulk formulas (Björk, 1989). Latent heat flux is calculated based on the monthly averaged humidity in a similar way. The thickness of the model snow layer is added to the ice thickness so that the result is comparable with the EM total thickness in the individual years. A more detailed description of the monthly mean forcing in the Barents Sea is provided by Smedsrud and others (2010).

\section{RESULTS}

Figure 5 shows the sea-ice thickness distributions derived from EM data of the three classes: (1) fast ice; (2) locally formed ice; and (3) advected external sea ice. In 2003, 

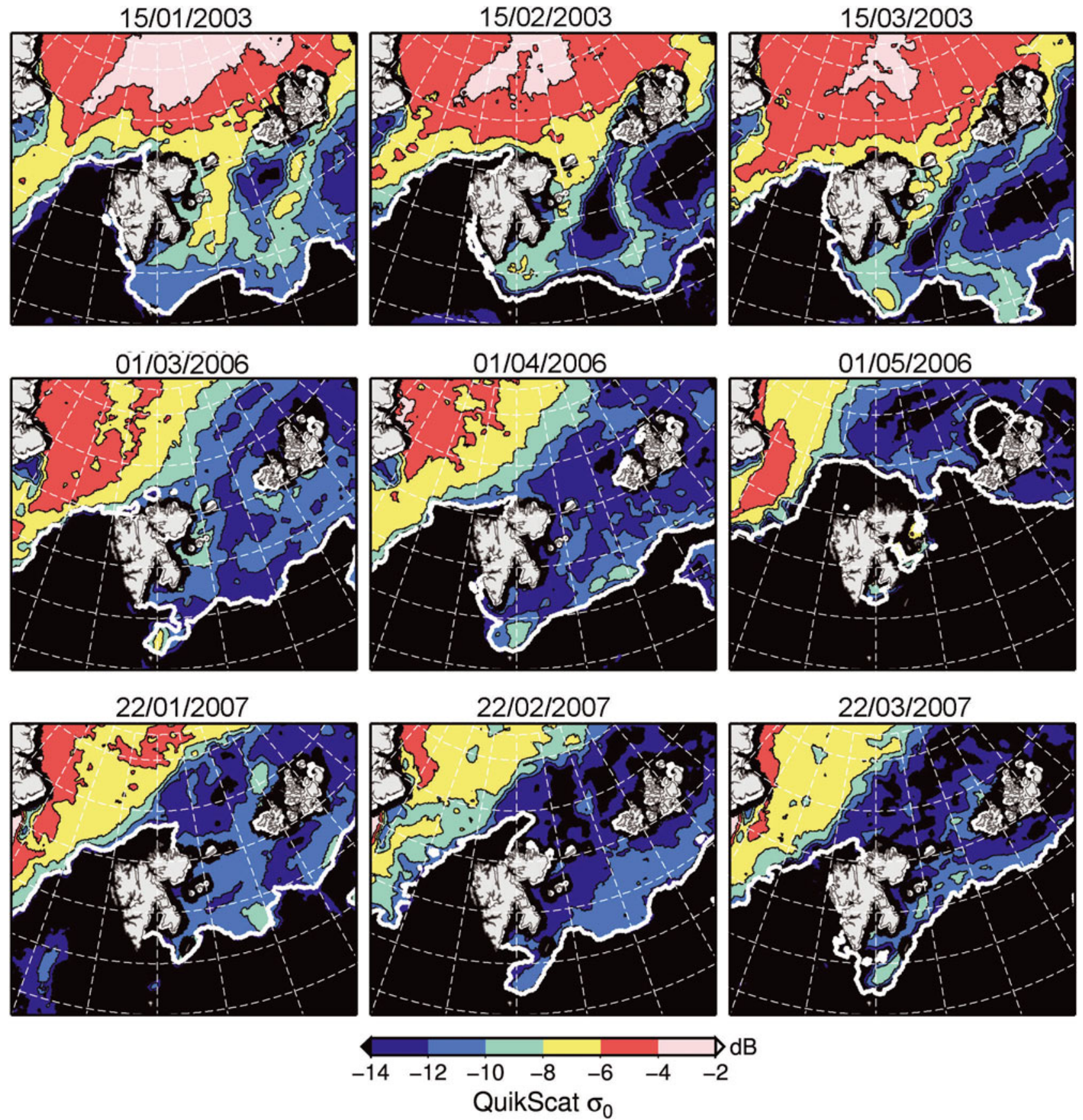

Fig. 3. QuikSCAT backscatter maps from the Barents Sea ranging back 2 months prior to the date of the data collection (right column). High backscatter (red) coincides with rougher multi-year ice, low backscatter (blue) with smoother first-year sea ice. The white line illustrates seaice edge derived by the $15 \%$ threshold of SSM/I sea-ice concentration data. Dates are $\mathrm{dd} / \mathrm{mm} / \mathrm{yyyy}$.

multi-year ice covered the southern part of the region while the central fjord was covered with thin ice from a polynya event. However, in 2006 southerly winds prevented the formation of a polynya and only thicker sea ice was found in the entire fjord. However, no apparent boundary could be identified in the SAR images or in the thickness data; therefore, most of the profile was classified as 'external sea ice' except the fast-ice zone close to the coast of Spitsbergen. The situation in 2007 resembled that of 2003; however, no external ice was found and no indications of the presence of multi-year ice were observed in SAR or QuikSCAT data at the southern entrance of Storfjorden. Visual observations from the ship's bridge confirm a gradual transition from open-water conditions into gradually thicker ice cover along the cruise track arriving in the fjord. Almost the entire dataset was identified as locally formed sea ice, with a small patch of fast ice in the northernmost part of the profile near Freemansundet.

The statistical parameters of all classes are summarized in Table 1. The thickest fast ice was found in 2003, with a mean thickness of $1.58 \pm 0.77 \mathrm{~m}$ (mean \pm 1 standard deviation) and a modal thickness of $1.0 \mathrm{~m}$. In 2006, fast ice in the same region as in 2003 was $20-40 \%$ thinner (mean: $1.25 \pm 0.96 \mathrm{~m}$; modal: $0.6 \mathrm{~m})$ followed by a further decrease in 2007 (mean: $0.80 \pm 0.52 \mathrm{~m}$; modal: $0.40 \mathrm{~m}$ ). However, the region of fast ice was at the entrance of Freemansundet and not close to the coast of Spitsbergen as in the two previous field campaigns. The number of data points in the fast-ice zone is comparable in all years and ranges between $5 \%$ and $12 \%$ of the collected ice-thickness data. The modal 

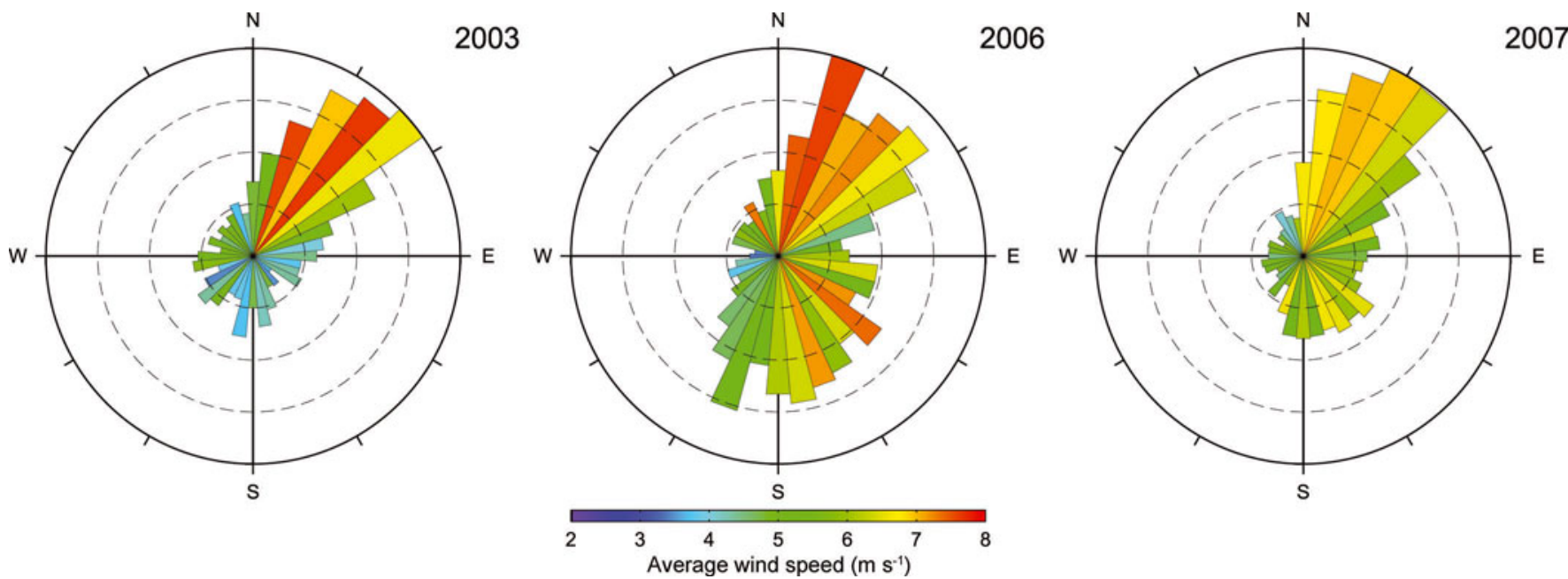

Fig. 4. Frequency of wind directions and average wind speed per bin from ECWMF reanalysis data in the 2 month period prior to the thickness data collection.

fast-ice thicknesses in each year are in agreement with results from the 1 DICE. The evolution of the thermodynamically grown total thickness is displayed in Figure 6, while Table 1 contains the values at the date of the field activities in the individual years. Differences in the model results reflect the variable air temperature over the time span of the runs with a colder year (2003) and warmer years $(2006,2007)$ than the long-term average. The comparison of model and field data shows that the behavior of the modal fast-ice thickness is very similar to the results of the ice growth model, though the thermodynamic thickness is consistently smaller. The difference (2003: $-4 \mathrm{~cm}$; 2006: $-13 \mathrm{~cm}$; 2007: $-4 \mathrm{~cm}$ ) may be caused by colder air temperatures in the fjord compared with the Barents Sea temperatures used for the 1-D model. In addition, the fast-ice surveys are confined to small geographical regions, which might introduce a local bias in the modal position. However, the difference between model and measurements lies within the bin size of the icethickness distribution.

The distributions of the local ice regimes sampled in 2003 and 2007 in Figure 5 show that the most common thicknesses do not exceed $1 \mathrm{~m}$. In 2007 the ice was thinner on average (mean: $0.37 \pm 0.44 \mathrm{~m}$ ) than in 2003 (mean $0.55 \pm 0.45 \mathrm{~m})$. The distribution mode indicates that $0.2 \pm 0.1 \mathrm{~m}$ was the most frequent thin-ice thickness in 2003, while in 2007 the modal thickness reveals more ice with a thickness $<10 \mathrm{~cm}$ and a higher open-water fraction. While the distribution in 2007 is more Gaussian-shaped, the trace of ice deformation is visible on the trailing flank of distribution in the thin-ice zone of 2003.

The thickest and most deformed sea ice can be found in the external ice class of $2003(1.83 \pm 1.05 \mathrm{~m})$ and 2006 $(2.21 \pm 1.04 \mathrm{~m})$. In contrast to the distributions of the other classes, the modes of the external sea ice in both years are less sharp, with a significantly broader basis. In 2006, the distribution is bimodal, with two maxima at 1.2 and $2.4 \mathrm{~m}$, although the two modes are not clearly separated. The two modes can be traced to different regions in Storfjorden (Fig. 7). The external ice class is categorized into a northern and southern part, which are divided by the $78^{\circ} \mathrm{N}$ zonal. This threshold was chosen slightly arbitrarily at a narrowing of the fjord. The northern part shows a pronounced maximum at a total thickness of $1.2 \mathrm{~m}$, which is the first mode in the combined distribution in Figure 5. Total thicknesses close to the second mode of $2.4 \mathrm{~m}$ are more common in the southern part of the fjord. Though the two distributions are quite different in shape, the mean values are similar (northern part: $2.10 \pm 1.22 \mathrm{~m}$; southern part: $2.28 \pm 1.01 \mathrm{~m})$

\section{DISCUSSION}

The snapshot measurements show the interannual variability of sea-ice thickness distributions in the confined region of Storfjorden. The comparability of the measurements is limited due to the layout of the field campaign, the

Table 1. Mean thickness, standard deviation, mode(s) of the ice-thickness distributions and number of data points in the individual ice classes in Storfjorden. The 1DICE column displays model results of snow plus ice thickness from a thermodynamic sea-ice model for the Barents Sea

\begin{tabular}{|c|c|c|c|c|c|c|c|c|c|c|c|c|c|}
\hline & \multicolumn{4}{|c|}{ Fast ice } & \multirow[t]{2}{*}{ 1DICE } & \multicolumn{4}{|c|}{ Local ice } & \multicolumn{4}{|c|}{ External ice } \\
\hline & Mean & Std dev. & Mode & No. & & Mean & Std dev. & Mode & No. & Mean & Std dev. & Mode & No. \\
\hline & $\mathrm{m}$ & $\mathrm{m}$ & $\mathrm{m}$ & & $\mathrm{m}$ & $\mathrm{m}$ & $\mathrm{m}$ & $\mathrm{m}$ & & $\mathrm{m}$ & $\mathrm{m}$ & $\mathrm{m}$ & \\
\hline 2003 & 1.58 & 0.77 & 1.0 & 7485 & 0.96 & 0.55 & 0.45 & 0.2 & 78360 & 1.83 & 1.05 & 1.8 & 66488 \\
\hline 2006 & 1.25 & 0.96 & 0.6 & 11144 & 0.47 & - & - & - & - & 2.21 & 1.04 & $1.2(2.4)$ & 131755 \\
\hline
\end{tabular}



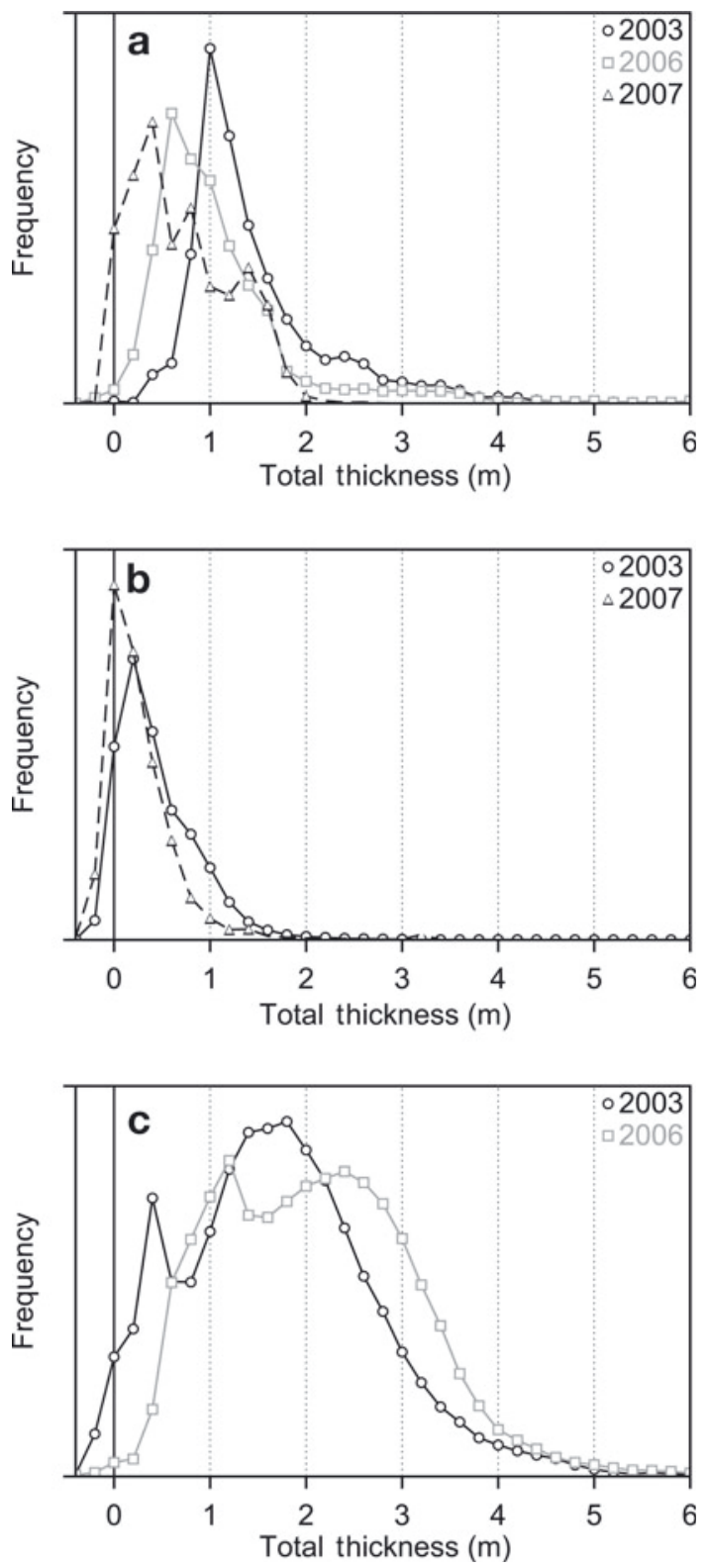

Fig. 5. Distributions of total (ice + snow) thickness of the three classes in Storfjorden: (a) fast ice, (b) locally formed ice and (c) advected external sea ice. The histogram bin size is $20 \mathrm{~cm}$. Negative thicknesses arise due to noise and instrument calibration errors.

time of year and the different external forcing. However, the imprints of the external conditions shown in 2 months prior to the surveys are clearly visible in the observed distribution functions.

In all years the modal fast-ice thickness is in good agreement with the 1-D model (Fig. 6), both for thicknesses above the long-term mean (2003) and well below (2006, 2007). Deviations between model and data might arise from differences in atmospheric forcing between Storfjorden and Hopen as well as sampling biases in the EM ice thickness due to the limited geographical coverage of fast ice in each year. However, the modeled thermodynamic ice thickness was not observed as a mode in the other ice-thickness distributions. Ice grown in a polynya is of younger age than fast ice and therefore thinner. Such local ice from the Storfjorden polynya was observed in 2003 and 2007. Both histograms vary in the frequency of very thin ice $(<0.2 \mathrm{~m})$. However, note that the accuracy of the measurements is not
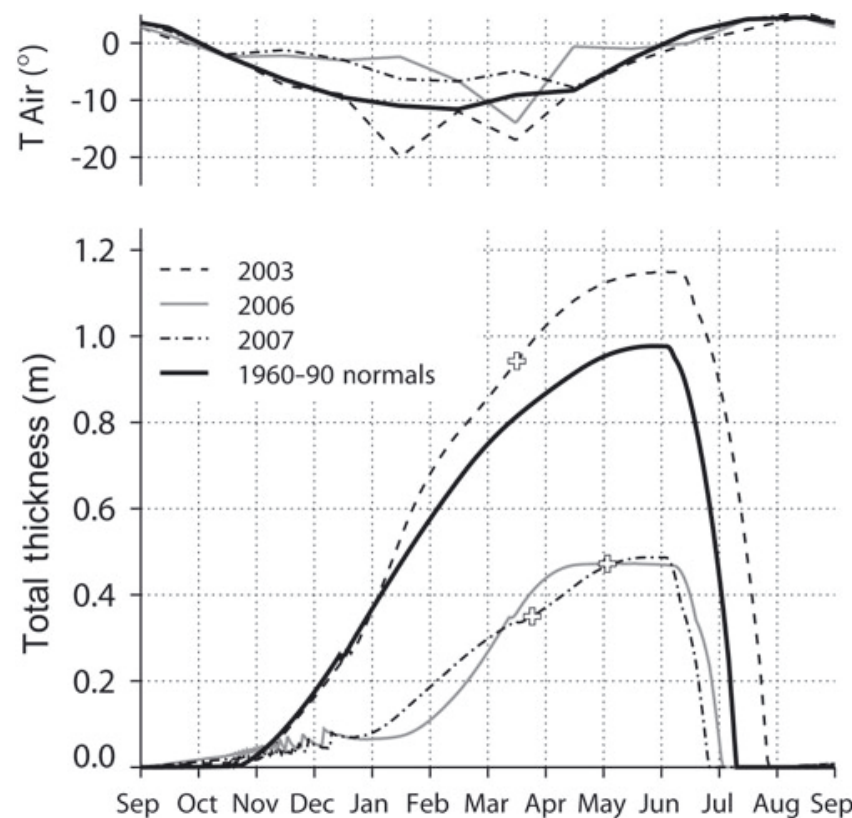

Fig. 6. Total ice thickness (bottom) from a thermodynamic sea-ice model (1DICE) representative for the western Barents Sea. Markers indicate the model thickness results at the dates of the surveys. The model was forced with monthly averaged precipitation and airtemperature data (top) from the weather station on Hopen.

sufficient to distinguish between the various thicknesses of this very thin ice just formed in the polynya, so observed differences between years may not be significant. The inaccuracy of the sensors causes a broader distribution as reflected in negative thicknesses in all histograms in Figure 5. Nevertheless, the local ice-thickness histograms show thicknesses exceeding the modeled thermodynamic ice thickness in both years (2003 and 2007). These tails of the local ice distributions are the result of ridging and rafting of thinner ice and show different shapes in 2003 and 2007. Though average wind speeds are different in both years (Fig. 4), an interpretation is difficult without a dedicated polynya model that reflects the differences of the thermodynamic and dynamic component in both years.

The absence of any local ice and the bimodal distribution of the external ice in 2006 indicate that strong deformation has taken place. One sea-ice core taken some days before

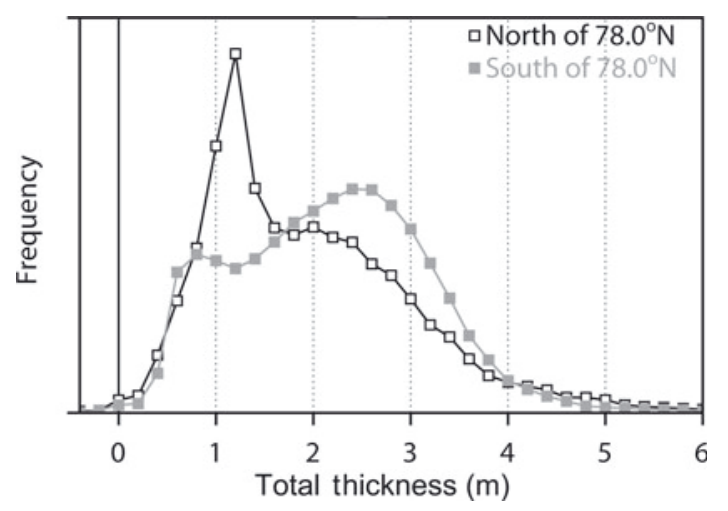

Fig. 7. Ice-thickness distribution of the external ice class in 2006 north and south of $78^{\circ} \mathrm{N}$. The sum of both distributions agrees with the distribution of external sea ice in Figure 5. 
the helicopter flight at the southern end of the area in Figure 2 showed evidence of several layers of rafted and deformed ice. The wind forcing of $\sim 6 \mathrm{~m} \mathrm{~s}^{-1}$ winds from the southwest (Fig. 4) would effectively raft and ridge the firstyear level ice of $0.6 \mathrm{~m}$ origin into thicker ice. For example, Amundrud and others (2004) showed that level ice $0.6 \mathrm{~m}$ thick north of Canada was deformed into large ridges with drafts between 5 and $18 \mathrm{~m}$.

In 2006 there were similar leading and trailing flanks of the thickness distribution functions in the northern and southern parts of the fjord (Fig. 7). The predominant southerly winds imply that the second mode in the ice-thickness distributions has been created by wind-forced deformation. The increase of the mean thickness in the southern part (+0.19 $\mathrm{m}$ or $9 \%$ compared with the north) is within the order of the expected sampling error of airborne EM surveys (Rabenstein and others, 2009). However, an increase of this magnitude by redistribution of $1.2 \mathrm{~m}$ thick ice into a $2.4 \mathrm{~m}$ thickness class is plausible, because the difference does describe two progressions of sea-ice deformation. In this case, the maximum at $2.4 \mathrm{~m}$ in the southern thickness distribution results from deformation processes and not thermodynamic growth of an older ice-thickness class. This mode may appear from extreme deformation events as observed in May 2006. However, it has to be kept in mind that the broadness of the mode may be caused partly by the local underestimation of deformed ice thickness by the EM method. The high degree of the deformation in 2006 is additionally illustrated by comparison with the external ice class in 2003. This ice is likely a part of the outflow event of thick multi-year ice in 2003 (Kwok and Rothrock, 2009). Here the mean thickness is about $40 \mathrm{~cm}$ smaller than in 2006 and the modal position is $40 \mathrm{~cm}$ larger.

The differences between modal and mean thicknesses underline the necessity of careful analysis of the complete ice-thickness distribution when comparing datasets with different external conditions. The modal thickness is a meaningful number to characterize certain ice regimes; however, histogram maxima may result from ice dynamics rather than thermodynamics. These dynamic modes can be separated from their thermodynamic counterparts by their less sharp appearance. This may be the case only for strong deformation events as observed here in a region very close to the coast, and the typical broader maxima of a multi-year ice distribution function are influenced by thermodynamics as well as dynamics.

\section{CONCLUSIONS}

We have presented a first assessment of ice thicknesses in the Storfjorden area from which previously no ice-thickness information was available despite the region's importance for atmosphere-ice-ocean interactions. The data show a wide range of sea-ice thickness distributions including very thin ice formed in a local polynya, fast ice close to the coast and thicker sea ice advected from the adjacent Barents Sea. Remote-sensing products, atmospheric reanalysis datasets as well as results from a 1-D thermodynamic growth model were used to assess the findings in the light of different external conditions. Therefore, this study provides valuable validation data for ice and polynya models of Storfjorden.

The ice-thickness data confirm that thermodynamic ice growth, as driven largely by air temperature, was approximately $0.5 \mathrm{~m}$ in 2006 and 2007. In 2003, and on average during recent decades, ice growth was approximately $1 \mathrm{~m}$ at the end of the freezing season, as reflected by the Storfjorden modal fast-ice thickness. Young locally grown ice in the Storfjorden polynya appears with very small (close to zero) modal thickness in the thickness distributions due to the chosen coarse bin size $(20 \mathrm{~cm})$. Thicker ice occurs less frequently, falling monotonically for increasing ice thickness. In 2003 deformed thick multi-year sea ice was advected into the southern part of Storfjorden from the Arctic Ocean, creating a mean and modal thickness of $1.8 \mathrm{~m}$. In 2006 strong southerly winds effectively ridged and rafted all locally grown ice into a thick cover with a bimodal distribution and a mean thickness of $2.2 \mathrm{~m}$. With airborne and ship-based EM it was possible for the first time to assess these variable regimes. The accessibility of Storfjorden with its range of ice thicknesses makes the region an ideal place for repeated studies of ice deformation and of suitability of the EM measurements to observe the resulting changes of the ice-thickness distribution.

\section{ACKNOWLEDGEMENTS}

We thank the crews of RV Polarstern and KV Svalbard and the pilots of Heli TransAir and Airlift for their outstanding support during the measurements. The provision of accommodation and technical assistance in Svea Nord by Store Norske Spitsbergen Kulkompani is much appreciated. The coordination and implementation of the field surveys was supported by NPI's center for ice, climate and ecosystems (ICE), the Bipolar Atlantic Thermohaline Circulation (BIAC), Det Norske Veritas' (DNV's) Ice Load Monitoring project and the DAMOCLES project. We are grateful to DNV for permission to use and show the 2007 ship-borne EM data. ECMWF ERA-40 datasets used in this study have been provided by the ECMWF data server; QuikSCAT and SSM/I data products have been obtained from Centre ERS d'Archivage et de Traitement (CERSAT), Institut Français pour I'Exploitation de la Mer. T. Krumpen is acknowledged for SAR image preparation.

\section{REFERENCES}

Amundrud, T.L., H. Melling and R. Grant Ingram. 2004. Geometrical constraints on the evolution of ridged sea ice. J. Geophys. Res., 109(C6), C06005. (10.1029/2003JC002251.)

Anderson, W.L. 1979. Numerical integration of related Hankel transforms of orders 0 and 1 by adaptive digital filtering. Geophysics, 44(7), 1287-1305.

Björk, G. 1989. A one-dimensional time-dependent model for the vertical stratification of the Upper Arctic Ocean. J. Phys. Oceanogr., 19(1), 52-67.

Björk, G. 1997. The relation between ice deformation, oceanic heat flux, and the ice thickness distribution in the Arctic Ocean. J. Geophys. Res., 102(C8), 18,681-18,698.

Gerland, S. and R. Hall. 2006. Variability of fast-ice thickness in Spitsbergen fjords. Ann. Glaciol., 44, 231-239.

Gerland, S., A.H.H. Renner, F. Godtliebsen, D. Divine and T.B. Løyning. 2008. Decrease of sea ice thickness at Hopen, Barents Sea, during 1966-2007. Geophys. Res. Lett., 35(6), L06501. (10.1029/2007GL032716.)

Haarpaintner, J., J. Gascard and P.M. Haugan. 2001. Ice production and brine formation in Storfjorden, Svalbard. J. Geophys. Res., 106(C7), 14,001-14,014.

Haas, C. 1998. Evaluation of ship-based electromagnetic inductive thickness measurements of summer sea-ice in the Bellingshausen 
and Amundsen Seas, Antarctica. Cold Reg. Sci. Technol., 27(1), $1-16$.

Haas, C. and P. Jochmann. 2003. Continuous EM and ULS thickness profiling in support of ice force measurements. In Loeset, S., B. Bonnemaire and M. Bjerkas, eds. Proceedings of the 17th International Conference on Port and Ocean Engineering under Arctic conditions (POAC'03), 16-19 June, 2003, Trondheim, Norway. Trondheim, Norwegian University of Science and Technology, 849-856.

Haas, C. and 7 others. 2004. Sea ice remote sensing, thickness profiling, and ice and snow analyses during Polarstern cruise Ark 19/1 / CryoVex2003 in the Barents Sea and Fram Strait, February 28-April 24, 2003. Bremerhaven, Alfred Wegener Institute for Polar and Marine Research. (Cruise Report.)

Haas, C., S. Hendricks and M.J. Doble. 2006. Comparison of the sea-ice thickness distribution in the Lincoln Sea and adjacent Arctic Ocean in 2004 and 2005. Ann. Glaciol., 44, 247-252.

Haas, C., J. Lobach, S. Hendricks, L. Rabenstein and A. Pfaffling. 2009. Helicopter-borne measurements of sea ice thickness, using a small and lightweight, digital EM system. J. Appl. Geophys., 67(3), 234-241.

Hendricks, S. 2008. Validierung von altimetrischen Meereisdickenmessungen mit einem helikopter-basierten elektromagnetischen Induktionsverfahren. (PhD thesis, University of Bremen.)

Kovacs, A., N.C. Valleau and J.S. Holladay. 1987. Airborne electromagnetic sounding of sea ice thickness and sub-ice bathymetry. Cold Reg. Sci. Technol., 14(3), 289-311.

Kwok, R. and D.A. Rothrock. 2009. Decline in Arctic sea ice thickness from submarine and ICESat records: 1958-2008. Geophys. Res. Lett., 36(15), L15501. (10.1029/2009GL039035.)
Kwok, R., W. Maslowski and S.W. Laxon. 2005. On large outflows of Arctic sea ice into the Barents Sea. Geophys. Res. Lett., 32(22), L22503. (10.1029/2005GL024485.)

Pfaffling, A. and J.E. Reid. 2009. Sea ice as an evaluation target for HEM modelling and inversion. J. Appl. Geophys., 67(3), 242-249.

Pfaffling, A., C. Haas and J.E. Reid. 2007. A direct helicopter EM sea ice thickness inversion, assessed with synthetic and field data. Geophysics, 72(4), F127-F137.

Rabenstein, L., S. Hendricks, C. Haas and T. Martin. 2009. Thickness and surface properties of sea-ice in the Arctic Trans Polar Drift: data from summer 2001, 2004 and 2007. J. Geophys. Res. (10.1029/2009JC005846R.)

Reid, J.E. and J. Vrbancich. 2004. A comparison of the inductivelimit footprints of airborne electromagnetic configurations. Geophysics, 69(5), 1229-1239.

Reid, J.E., A. Pfaffling and J. Vrbancich. 2006. Airborne electromagnetic footprints in one-dimensional earths. Geophysics, 71(2), G63-G72.

Skogseth, R., P.M. Haugan and J. Haarpaintner. 2004. Ice and brine production in Storfjorden from four winters of satellite and in situ observations and modeling. J. Geophys. Res., 109(C10), C10008. (10.1029/2004JC002384.)

Smedsrud, L.H., R. Ingvaldsen, J.E.Ø. Nilsen and Ø. Skagseth. 2010. Heat in the Barents Sea: transport, storage, and surface fluxes. Ocean Sci., 6(1), 219-234.

Uto, S., T. Toyota, H. Shimoda, K. Tateyama and K. Shirasawa. 2006. Ship-borne electromagnetic induction sounding of sea-ice thickness in the southern Sea of Okhotsk. Ann. Glaciol., 44, 253-260. 